\title{
Selective cell death in glaucoma: does it really occur?
}

This issue of the British Fournal of Ophthalmology breaks new ground. The perspective by Morgan looks at evidence that chronic human glaucoma selectively damages larger retinal ganglion cells. The acceptance of parallel processing in the primate visual system means selective death of large ganglion cells in early glaucoma should allow selective psychophysical testing for the identification of early disease. Morgan questions this in his paper. The journal invited a discussion by Professor Harry Quigley of Johns Hopkins Hospital, Baltimore, Maryland whose work is extensively quoted in the paper by Morgan. In his response Professor Quigley strongly confirms his view that selective cell death does occur in glaucoma. As this has immediate relevance for our understanding of the pathogenesis of the disease as well as the usefulness of psychophysical tests for its early detection it is important for ophthalmologists to know of this discussion.

R A HITCHINGS

Moorfields Eye Hospital

City Road, London ECIV 2PD 